\title{
Integrating remote sensing and diver observations to predict the distribution of invasive lionfish on Bahamian coral reefs
}

\author{
Alexandra C. D. Davis* \\ Oregon State University, Department of Integrative Biology, 3029 Cordley Hall, 2701 SW Campus Way, Corvallis, \\ OR 97331, USA
}

Present address: Department of Biological Sciences, University of Alberta, CW 405, Biological Sciences Building, Edmonton, AB T6E 4R4, Canada

ABSTRACT: The ongoing invasion of coral reefs in the greater Caribbean region by Indo-Pacific lionfish (Pterois spp.) poses challenges for managers. Although the dynamics and ecological effects of lionfish invasions have been examined in detail at the scale of individual reefs, relatively little information is available on the patterns of the invasion over larger areas. This study combined species counts and microhabitat observations from SCUBA surveys with satellite-derived bathymetry and habitat data to create predictive species distribution maps of lionfish in a $58 \mathrm{~km}^{2}$ region along the southern edge of the island of Eleuthera in the Bahamas. Models predicted lionfish presence, absence, and density, and were created iteratively using various resolutions and types of data to mimic the datasets that may be available to management in the region. The best-fit model for presence and absence, which combined physical variables derived from remotely sensed satellite data and diver-collected microhabitat data, predicted $89 \%$ of lionfish presence and absence. The best-fit model for lionfish density used 2 resolutions of physical habitat data as well as biological data on densities of large native groupers and accurately predicted $67 \%$ lionfish density. These results suggest that physical habitat may be more important for initial lionfish presence and that biotic interactions influence lionfish density on the reefs. Understanding the limitations and value of each type of data when creating models may be advantageous for planning targeted lionfish removals and prioritizing sites for conservation efforts.

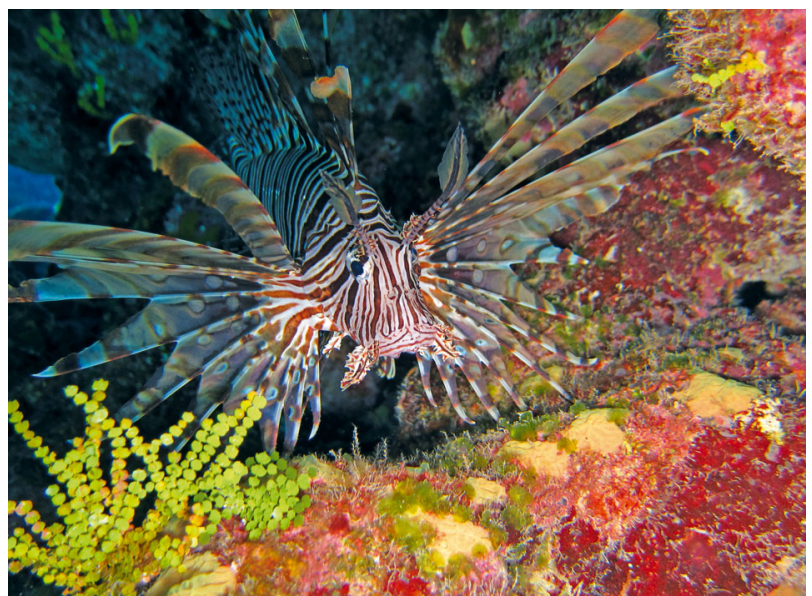

Pacific lionfish (Pterois sp.) in a reef crevice in Eleuthera, The Bahamas, which is part of the invaded Caribbean range.

Image: Tye L. Kindinger

KEY WORDS: Lionfish - Pterois - Species distribution models - Remote sensing - Invasive species · Habitat mapping

\section{INTRODUCTION}

Species distribution modeling is a useful tool to predict expansion or contraction of species' ranges (Rodríguez-Castañeda et al. 2012), and has become widespread in conservation biology and wildlife

(C) The author 2019. Open Access under Creative Commons by Attribution Licence. Use, distribution and reproduction are unrestricted. Authors and original publication must be credited. 
management (Araújo \& Guisan 2006). Species distribution maps, including habitat suitability maps, may be based on predicted presence and absence (Guisan \& Thuiller 2005). Many habitats are characterized by physical features that do not change rapidly (McComb et al. 2010); however, biotic interactions may alter species distributions over time and are more difficult to quantify (Araújo \& Guisan 2006). The availability of remotely sensed bathymetry now provides the opportunity to create physical habitat maps for use in marine ecosystems (Pittman et al. 2007, Pittman \& Olds 2015, Roelfsema et al. 2018).

Species distribution modeling has been used for tracking the spread of invasive species and for planning control efforts (Václavík \& Meentemeyer 2009, Gallien et al. 2012, Petitpierre et al. 2012). However, species distribution models are heavily focused on terrestrial systems, and use of these models has typically been limited in marine systems, despite the fact that species invasions are a pressing issue for management (Robinson et al. 2011). Invasive species can alter or disrupt functioning ecosystems (Pyšek \& Richardson 2010) by overconsuming or outcompeting native species for resources, changing nutrient cycling, and overall altering food webs and community structure (Molnar et al. 2008). The rate of spread of invasive species is attributed to a complex combination of factors (Catford et al. 2011), such as native biotic resistance (Kimbro et al. 2013, Byun \& Lee 2017), ecological release (Keane \& Crawley 2002, Colautti et al. 2004, Kimbro et al. 2013), and the ecological landscape of the invaded range (Baltz \& Moyle 1993, Collinge et al. 2011). Because species interactions and complex community interactions may be more difficult to quantify than physical habitat, using suitable habitat to predict where invasive species occur may be a more practical and general approach.

Invasive Indo-Pacific lionfish (Pterois spp.) were introduced to the subtropical western Atlantic late in the last century and have now spread throughout the greater Caribbean (Schofield 2009), including the Gulf of Mexico (Whitfield et al. 2007, Schofield 2010), and into South American coastal waters (Evangelista et al. 2016). Lionfish greatly reduce recruitment of ecologically and economically important fish species on reefs (Albins \& Hixon 2008, Albins 2015, Ingeman 2016, Kindinger \& Albins 2017, Tuttle 2017), including extirpation in some cases (Benkwitt 2013, Ingeman \& Webster 2015, Ingeman 2016). Locating and removing lionfish is now a major goal for conservation of coral reefs in the Caribbean (Frazer et al. 2012, de León et al. 2013, Hackerott et al. 2013, Green et al. 2014, Usseglio et al. 2017). However, current management options for controlling lionfish populations are limited to manual searching and removal by divers using spears or nets, which are labor intensive and time consuming (Green et al. 2014). More comprehensive regional mapping of lionfish distribution would allow management to prioritize removal efforts.

Invasive lionfish (Fig. 1) prefer rugose (roughtextured) seafloors, where they can find cracks and caves in which to shelter during the daytime when not feeding and where there are strong currents (Fishelson 1997). Thus, reefs, which often contain one of more of these features, provide suitable habitat for lionfish. However, lionfish are not limited to reef structures; they also occur in seagrass beds (Kulbicki et al. 2012, Benkwitt 2016b), mangroves (Barbour et al. 2010, Pimiento et al. 2013), river estuaries (Jud \& Layman 2012, Kulbicki et al. 2012), and on reef slopes as deep as 100 m (Lesser \& Slattery 2011, Nuttall et al. 2014) and are often characterized as habitat generalists (Cure et al. 2014). It remains unclear whether lionfish are attracted to reefs because of the highly complex structure, or are responding to some aspects of the biotic community, such as prey abundance, or both. Lionfish may leave small patch reefs at dusk, hunt at night, and return to reefs at dawn, suggesting that they are attracted to reefs as shelter, and not necessarily by the prey assemblage on the reef (Benkwitt 2016a,b). Moreover, large iso-

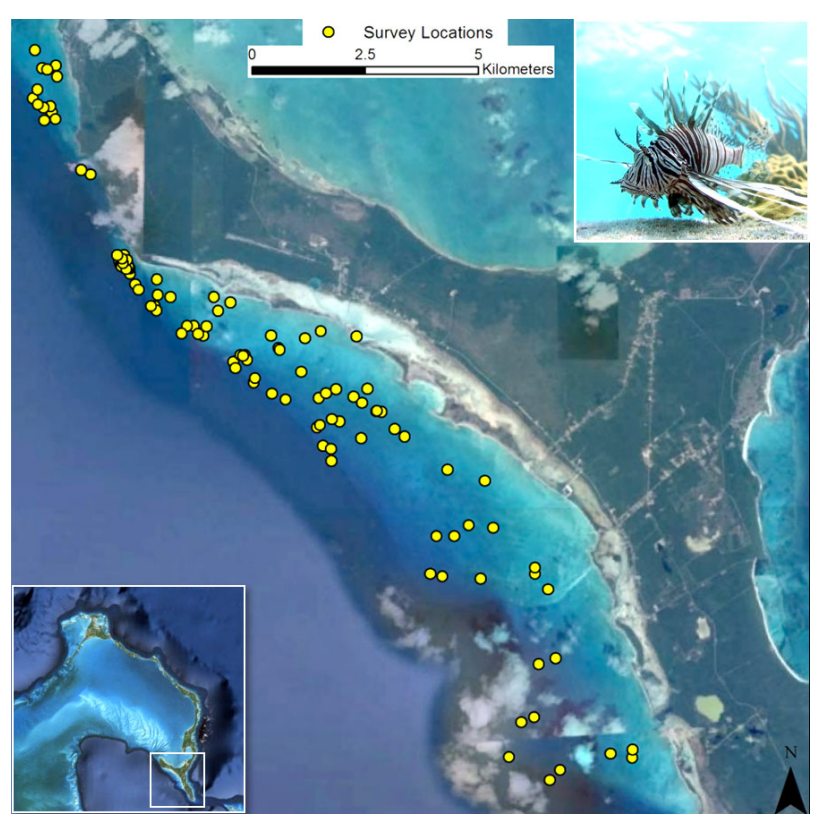

Fig. 1. Eleuthera, the Bahamas (inset lower left). Main map shows the southern edge of the island where all observations were conducted; yellow dots indicate the survey sites. Also shown is an invasive lionfish in the invaded range (photo by Mark A. Albins) 
lated reefs with high complexity, but relatively low prey fish availability, have supported high densities of lionfish for up to $9 \mathrm{wk}$ (Davis 2018). On the other hand, high densities of large Nassau grouper Epinephelus striatus can interfere with lionfish hunting and may be a deterrent for lionfish to remain on small patch reefs (Pusack 2013, Raymond et al. 2015, and see Ellis \& Faletti 2016 for red grouper E. morio).

Despite many studies of invasive lionfish in the greater Caribbean region, little is known of the finescale regional distribution of lionfish. No studies have yet applied species distribution modeling to describe the spatial pattern of invasive lionfish presence/absence. Available reef maps are typically of very coarse resolution and may not provide information needed at the scale necessary to guide divers to fine-scale locations of lionfish. For example, much of the knowledge of reefs in the Bahamas is obtained from images derived from Google Earth or coarseresolution maps such as nautical charts or databases of coral cover (e.g. ReefBase, www.reefbase.org). Higher-resolution habitat and species distribution maps may therefore improve conservation efforts in the Bahamas and elsewhere.

The goals of this study were:

(1) to map the distribution of invasive lionfish based on coarse-scale, satellite-derived seafloor habitat classification and physical habitat features, and to evaluate map accuracy as a test of the hypothesis that lionfish will be found in more complex habitats;

(2) to map the distribution of lionfish based on finescale physical habitat features and a biotic factor, specifically the abundance of large groupers, and evaluate map accuracy as a test of the hypothesis that diver-obtained microhabitat and biological data will improve the model;

(3) to present a method of species distribution modeling for lionfish that can be modified and used in other locations within the invasive range of lionfish by ranking the importance of types of data for predicting lionfish distribution.

\section{MATERIALS AND METHODS}

\subsection{Study area}

This study was conducted during the summer months (May-September) of 2013-2016 on the southwest end of the island of Eleuthera, the Bahamas $\left(24.83^{\circ} \mathrm{N}, 76.33^{\circ} \mathrm{W}\right.$; Fig. 1). The system consists mainly of reefs separated by sand and seagrass beds, producing patches with varying degrees of isolation, as well as areas of spur and groove reef on the Exuma Sound side of Cape Eleuthera. The Exuma Sound is exposed to prevailing trade winds (NE-SE), and the coastal shelf ranges in depth from 3 to $25 \mathrm{~m}$. Beyond the coastal shelf, the seafloor drops abruptly to 2000 m depth.

\subsection{Reefs surveyed}

Study reefs were chosen based on 2 criteria to encompass (1) the natural range of reefs on the shelf using knowledge of the area gained from previous studies (Pusack et al. 2014, Ingeman 2016, Kindinger \& Anderson 2016), and (2) a naturally occurring range of lionfish densities. From 2013 through 2016, 8 to 12 reefs were surveyed annually, with some reefs surveyed in multiple years, for a total of 23 unique reefs. In 2016, 13 new reefs were added to the 23 reefs already surveyed for a total of 36 reefs. The resulting sample of 36 study reefs ranged in size from 100 to $1200 \mathrm{~m}^{2}$, with an average area of $550 \mathrm{~m}^{2}$, and ranged in depth from 4 to $25 \mathrm{~m}$. Study reefs also varied in vertical relief and microhabitat structure. Additionally, in 2016, sampling was done on a set of 90 points distributed over the $58 \mathrm{~km}^{2}$ study area, including all habitat types. Points were selected using the random point generator in ArcGIS (v. 10.2.2). This resulted in a total of 126 sample points.

Surveys were conducted throughout the study season (May-September) in each year except 2013, when data were available only for June. All surveys were conducted by a pair of SCUBA divers during daylight hours between 10:00 and 17:00 h. Survey time varied depending on reef size and complexity, and lasted 30-60 min, and each random point survey lasted 10-30 min.

\subsection{Fish and invertebrate surveys}

\subsubsection{Invasive lionfish}

Between 2013 and 2016, each of the 36 reefs, including a $10 \mathrm{~m}$ diameter buffer of surrounding sand or coral-rubble seafloor, was thoroughly searched for lionfish by divers using dive lights to examine all cracks and crevices. In addition to the reef surveys in 2016, a 20 m diameter circular plot was surveyed at each of the 90 randomly located points. All lionfish seen were counted, visually sized for total length (TL) to the nearest centimeter, and their locations mapped. 


\subsubsection{Native species}

Reef surveys were conducted for large native piscivorous groupers (potential predators of lionfish and potential competitors for food). Additionally, surveys included prey-sized fish (the known primary forage base of lionfish; Morris \& Akins 2009, Valdez-Moreno et al. 2012, Côté et al. 2013, Dahl \& Patterson 2014, Arredondo-Chávez et al. 2016) and large mobile invertebrates such as Caribbean spiny lobster Panulirus argus and longspine urchin Diadema antillarum, which occupy cracks and crevices similarly to lionfish. However, prey survey data were not available at all reefs, and invertebrates were observed at such low densities that both of these data sets were excluded from the final models. All fish and invertebrates were counted and fish were visually sized to the nearest cm TL.

\subsection{Habitat mapping}

Bathymetric data points derived using World View2/3 satellite images of the southwest coast of Eleuthera, the Bahamas, were obtained from EOMAP (www.eomap.com). The vertical accuracy of the data was $2 \mathrm{~m}$ grid spacing and the horizontal accuracy was $\pm 0.5 \mathrm{~m}$ for the entire $58 \mathrm{~km}^{2}$ study area. Point data were imported into ArcGIS 10.2 and used to create a digital elevation model (DEM) for the $58 \mathrm{~km}^{2}$ study area. Habitat variables were generated from the DEM using the 'Benthic Terrain Modeler 3.0' plugin for ArcGIS (Wright et al. 2012, Walbridge et al. 2018), including depth, rugosity, bathymetric position index (BPI, a measure of peaks and valleys relative to a designated neighborhood size), and first derivative of slope (curvature) (Table 1, Fig. 2).

At each of the 126 survey points where lionfish were sampled, surveys were completed of fine-scale physical habitat, including the location of reef cracks ( $<2$ m diameter, i.e. below the resolution of the satellite data), ledges and caves, and surrounding substrate (e.g. sand, hard bottom, seagrass). At the 90 randomly located points sampled in 2016, substratum was classified in a $20 \mathrm{~m}$ diameter circular plot. If the random point landed on an isolated reef, reef area measurements were taken and any small cracks, ledges, and caves were noted (Fig. 2F).

\subsection{Model design}

The objective of this study was to test how various types and spatial scales of data might help predict the local distribution of lionfish. Models were con-

Table 1. Description of satellite bathymetry products used for habitat classification, and diver obtained microhabitat and biotic observations. No tool was used to create the seafloor habitat layer because the product was produced by EOMAP (www.eomap.com). BTM: Benthic Terrain Modeler (ArgGIS)

\begin{tabular}{|c|c|c|c|}
\hline Variables & Description & Tool used & $\begin{array}{l}\text { Variable form used in } \\
\text { modeling }\end{array}$ \\
\hline \multicolumn{4}{|c|}{ Derived from satellite bathymetry } \\
\hline Depth & $\begin{array}{l}\text { Water depth for each cell, derived from World } \\
\text { View satellite images }\end{array}$ & $\begin{array}{l}\text { Point to raster } \\
\text { conversion tool }\end{array}$ & Continuous \\
\hline Rugosity & $\begin{array}{l}\text { Ratio between straight-line distance and the } \\
\text { 3-dimensional distance }\end{array}$ & $\begin{array}{l}\text { Rugosity tool in } \\
\text { BTM }\end{array}$ & Continuous \\
\hline $\begin{array}{l}\text { Bathymetric position } \\
\text { index (BPI) }\end{array}$ & $\begin{array}{l}\text { Measure of a cell's depth relative to its surround- } \\
\text { ings at a designated scale (here } 50 \mathrm{~m} \text { ) }\end{array}$ & $\begin{array}{c}\text { Broad-scale and } \\
\text { fine-scale BPI tools } \\
\text { in BTM }\end{array}$ & Continuous \\
\hline Curvature & $\begin{array}{l}\text { Degree to which something deviates from a } \\
\text { straight line }\end{array}$ & $\begin{array}{l}\text { Curvature tool in } \\
\text { BTM }\end{array}$ & Continuous \\
\hline Seafloor habitat layer & $\begin{array}{l}\text { Classification of seafloor by EOMAP based on } \\
\text { seafloor reflectance and spectral characteristics }\end{array}$ & Not applicable & $\begin{array}{c}\text { Categorical } \\
\text { (Unconsolidated } \\
\text { sediment }[\mathrm{US}]_{;} \\
\text {Hardbottom with algae } \\
{[\mathrm{HA}]_{;} \text {Hardbottom }[\mathrm{H}]_{i}} \\
\text { and Coral }[\mathrm{C}] \text { ) }\end{array}$ \\
\hline \multicolumn{4}{|c|}{ Derived from diver observations } \\
\hline Microhabitat & $\begin{array}{l}\text { Binary presence of caves, ledges, or cracks } \\
\text { (diameter }<2 \mathrm{~m} \text { ) at survey location }\end{array}$ & Diver observations & Categorical (1-3) types \\
\hline Grouper density & Density of adult groupers at each survey location & Diver observations & Continuous \\
\hline
\end{tabular}




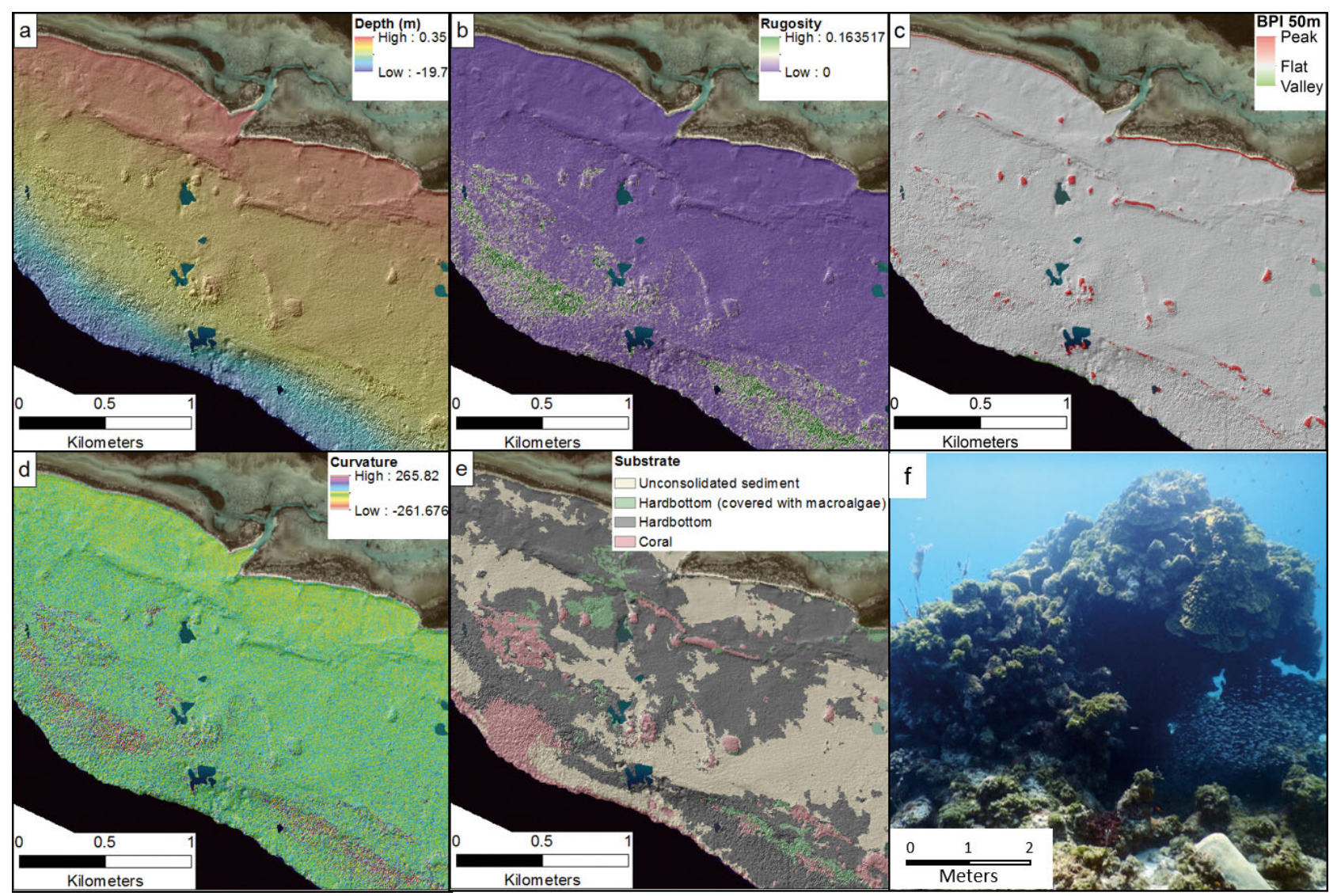

Fig. 2. Bathymetric variables used in the models: (a) depth, (b) rugosity, (c) bathymetry position index (BPI), (d) curvature, and (e) categorical substrate. (f) Overhanging ledge feature in one of the study reefs

structed to test how lionfish presence and absence (or density) were related to various measures of habitat complexity. Habitat complexity variables have been shown to correlate with the local distributions of marine species (Gratwicke \& Speight 2005, Rilov et al. 2007) and have been used in modeling distributions of marine fishes (Pittman et al. 2007, Young et al. 2010).

A set of models was created using 4 datasets with variables as the independent predictors of suitable lionfish habitat (Table 1). Predictor variables included (1) remotely sensed seafloor habitat provided by EOMAP, including 4 seafloor habitats (coral reef, hard bottom, hard bottom with algae, and unconsolidated sediment) classified based on seafloor reflectance and spectral characteristics; (2) coarse-scale physical habitat derived from remotely sensed bathymetry, such as depth, slope, aspect, curvature, rugosity, and $\mathrm{BPI}_{i}$ (3) field-collected, physical variables based on data collected by divers, i.e. fine-scale physical habitat features such as caves and ledges as well as cracks $<2 \mathrm{~m}$ (i.e. resolution of the remotely sensed data); and (4) field-collected biotic variables, based on data collected by divers, i.e. the density of large groupers (i.e. potential biotic interactions).

Generalized additive models (GAMs) were run using the 'gam' function in the R statistical package for ArcGIS (R Development Core Team 2008, Roberts et al. 2010). GAMs are flexible models that can be used with non-linear data (common in ecological studies), and can also account for data which do not have equal variance (Guisan \& Thuiller 2005, Zuur et al. 2009).

GAMs were fit in an iterative process in which a full model using all available variables was created, and then variables were removed or replaced successively until the best-fit model was created. Model fit was assessed using deviance explained and variable significance. The deviance of a generalized linear model is twice the difference in loglikelihood between the proposed model and a saturated model (a model with as many parameters as there are observations). For a Gaussian family, this is the usual residual sum of squares, and the percentage deviance explained is exactly R-squared. For non-Gaussian families, the percentage deviance explained provides an analog of R-squared that can 
help quantify the goodness of fit of a model. Presence and absence models were fit with a binomial distribution, and density models were fit with a Gaussian distribution. All presence/absence data were true presence and absence data, i.e. absences are locations that have been surveyed and species were not observed, rather than presence-only data where absences are inferred (Koshkina et al. 2017). Models were constructed using $70 \%$ of the data $(\mathrm{n}=$ 76). Predictive accuracy of the models was calculated by comparing actual presence, absence, or density observations to the predicted distribution from the model using the remaining $30 \%$ of data $(\mathrm{n}=39)$. Statistical significance was determined using an alpha value $\leq 0.05$.

Various subsets of the variables in the best-fit model (Model 1) were created to simulate different scenarios of data availability. Models 2 and 3 were habitat-only models. Model 2 included all available physical habitat data, including the physical habitat variables derived from remotely sensed bathymetry, i.e. depth, slope, aspect, curvature, rugosity, and BPI, as well as the 4 classes included in the seafloor habitat classification layer, and the micro-habitat diver collected data. Model 3 was a coarse-scale model that included only the habitat features that could be derived from the remotely sensed bathymetry data and omitted the diver-collected data, i.e. a broadscale model. Models 4-6 were based only on divercollected data. For the full model (Model 4) this included both biotic data on grouper densities as well as the micro-habitat data. Model 5 included only diver-collected biotic data, and Model 6 included only data on the presence of microhabitat features. Response variables for all models were either lionfish presence and absence (Models PA1-PA6) or lionfish density (Models D1-D6).

Additional GAMs were run to detect any relationship between lionfish density and prey density on the subset of reefs where these data was available.

\section{RESULTS}

\subsection{Lionfish presence and absence}

Model PA1, which used derived coarse-scale physical habitat features and diver-collected finescale physical habitat data, accurately predicted lionfish presence or absence $89 \%$ of the time (Table 2). Microhabitat was the only significant variable, with 1 or 2 microhabitat features significantly correlated (GAM, p $=0.014$ and <0.0001, respectively), and explained $68 \%$ of the deviance.

Table 2. Results from the generalized additive models (GAMs) for lionfish presence and absence used to associate target species with habitat and biotic predictors. BPI: bathymetric position index. Bold indicates significant values ( $\mathrm{p} \leq 0.05)$

\begin{tabular}{|c|c|c|c|c|c|}
\hline Model & $\begin{array}{l}\text { Variable } \\
\text { type }\end{array}$ & Predictors & $\mathrm{p}$ & $\begin{array}{l}\text { Total deviance } \\
\text { explained } \\
\text { (pseudo } \mathrm{R}^{2} \text { ), \% }\end{array}$ & $\begin{array}{l}\text { Predictive } \\
\text { accuracy, \% }\end{array}$ \\
\hline PA1 & All & $\begin{array}{l}\text { Microhabitat }(1,2 \text { or } 3 \text { types }) \\
\text { Rugosity } \\
\text { BPI }\end{array}$ & $\begin{array}{c}\mathbf{0 . 0 1 4},<\mathbf{0 . 0 0 1}, 0.991 \\
0.425 \\
0.995\end{array}$ & 68 & 89 \\
\hline PA2 & $\begin{array}{l}\text { Habitat only } \\
\text { (full) }\end{array}$ & $\begin{array}{l}\text { Seafloor habitat (US, HA, H, C) } \\
\text { Microhabitat }(1,2 \text { or } 3 \text { types) } \\
\text { Rugosity } \\
\text { BPI } \\
\text { Depth } \\
\text { Curvature }\end{array}$ & $\begin{array}{c}1.000,0.997,1.000,0.999 \\
0.994,0.994,0.995 \\
0.606 \\
0.995 \\
0.252 \\
0.524\end{array}$ & 84 & 95 \\
\hline PA3 & $\begin{array}{l}\text { Habitat only } \\
\text { (broad-scale) }\end{array}$ & $\begin{array}{l}\text { Seafloor habitat (US, HA, H, C) } \\
\text { Rugosity } \\
\text { BPI } \\
\text { Depth } \\
\text { Curvature }\end{array}$ & $\begin{array}{c}0.637,0.986,0.816,0.509 \\
\mathbf{0 . 0 0 3} \\
0.984 \\
0.678 \\
0.227\end{array}$ & 38 & 76 \\
\hline PA4 & $\begin{array}{l}\text { Diver collected } \\
\text { (full) }\end{array}$ & $\begin{array}{l}\text { Microhabitat (1, } 2 \text { or } 3 \text { types }) \\
\text { Grouper density }\end{array}$ & $\begin{array}{c}\mathbf{0 . 0 1 8 9},<\mathbf{0 . 0 0 1}, 0.986 \\
0.393\end{array}$ & 67 & 87 \\
\hline PA5 & $\begin{array}{l}\text { Diver collected } \\
\text { (biotic) }\end{array}$ & Grouper density & 0.001 & 16 & 86 \\
\hline PA6 & $\begin{array}{c}\text { Diver collected } \\
\text { (habitat) }\end{array}$ & Microhabitat (1, 2 or 3 types) & $\mathbf{0 . 0 0 5}, \ll 0.001,0.986$ & 66 & 87 \\
\hline
\end{tabular}


Model PA2, which used all available habitat data, accurately predicted lionfish presence and absence $95 \%$ of the time (Table 2). None of the variables was significant, and the model explained $84 \%$ of the deviance. Model PA3, based on spectrally derived seafloor habitat data and the broad-scale habitat layers, accurately predicated lionfish presence and absence $76 \%$ of the time (Table 2). Rugosity was the only significant variable in the model (GAM, p = 0.003), and the deviance explained was $38 \%$. Model PA4 included only variables that were collected by divers and accurately predicted lionfish presence and absence $87 \%$ of the time (Table 2). Microhabitat was the only significant variable, with 1 or 2 microhabitat features significantly correlated (GAM, p $=0.019$ and <0.0001, respectively), and explained $67 \%$ of the deviance. Model PA5, which used only the density of native grouper, accurately predicted lionfish presence and absence $86 \%$ of the time (GAM, $\mathrm{p}=0.001$, Table 2), but only explained $16 \%$ of the deviance. Model PA6 used only the diver-collected microhabitat variables and accurately predicted lionfish presence and absence $87 \%$ of the time (Table 2). Locations with 1 or 2 microhabitat features present were significant (GAM, $\mathrm{p}=$ 0.008 and $\ll 0.001$, respectively) and explained $66 \%$ of the deviance.

\subsection{Lionfish density}

Model D1, which used derived coarse-scale physical habitat features, diver-collected fine-scale physical habitat data, and diver-collected biotic data on grouper densities, accurately predicted lionfish density $72 \%$ of the time (Table 3 ). Microhabitat and grouper density were both significant (GAM, $\mathrm{p}<0.0001,=0.0002$, and $=0.043$, for presence of 2 or 3 microhabitat features and grouper density, respectively), and explained $50 \%$ of the deviance. Model D2, which used all available habitat data, accurately predicted lionfish density $70 \%$ of the time (Table 3). Microhabitat was the only significant variable (GAM, $\mathrm{p}=0.044,<0.0001$, and $<0.001$, respectively), and explained $48 \%$ of the deviance. Model D3, based on spectrally derived seafloor habitat data and the broad-scale derived habitat layers, accurately predicated lionfish density $67 \%$ of the time (Table 3 ). Rugosity was the only significant variable in the model (GAM, p = 0.018), and the deviance explained was $18 \%$. Model D4 included only variables that were collected by divers and accurately predicted lionfish density $49 \%$ of the time (Table 3). Microhabitat was the only significant variable, with 2 or 3 microhabitat features significantly correlated with lionfish density (GAM, p $<0.0001$ and $<0.0001$, respectively), and ex-

Table 3. Results from the generalized additive models (GAMs) for lionfish density used to associate target species with habitat and biotic predictors. BPI: bathymetric position index. Bold indicates significant values $(p \leq 0.05)$

\begin{tabular}{|c|c|c|c|c|c|}
\hline Model & $\begin{array}{l}\text { Variable } \\
\text { type }\end{array}$ & Predictors & $\mathrm{p}$ & $\begin{array}{l}\text { Total deviance } \\
\text { explained } \\
\left(\text { pseudo } \mathrm{R}^{2}\right), \%\end{array}$ & $\begin{array}{c}\text { Predictive } \\
\text { accuracy, \% }\end{array}$ \\
\hline D1 & All & $\begin{array}{l}\text { Microhabitat }(1,2 \text { or } 3 \text { types }) \\
\text { Curvature } \\
\text { Grouper density }\end{array}$ & $\begin{array}{c}0.229,<\mathbf{0 . 0 0 0 1 , ~} \mathbf{0 . 0 0 0 2} \\
0.071 \\
\mathbf{0 . 0 4 3}\end{array}$ & 50 & 72 \\
\hline D2 & $\begin{array}{l}\text { Habitat only } \\
\text { (full) }\end{array}$ & $\begin{array}{l}\text { Seafloor habitat (US, HA, H, C) } \\
\text { Microhabitat (1, } 2 \text { or } 3 \text { types) } \\
\text { Rugosity } \\
\text { BPI } \\
\text { Depth } \\
\text { Curvature }\end{array}$ & $\begin{array}{c}0.710,0.842,0.597,0.393 \\
\mathbf{0 . 0 4 4},<\mathbf{0 . 0 0 0 1 ,}<\mathbf{0 . 0 0 1} \\
0.572 \\
0.376 \\
0.519 \\
0.080\end{array}$ & 48 & 70 \\
\hline D3 & $\begin{array}{l}\text { Habitat only } \\
\text { (broad-scale) }\end{array}$ & $\begin{array}{l}\text { Seafloor habitat (US, HA, H, C) } \\
\text { Rugosity } \\
\text { BPI } \\
\text { Depth } \\
\text { Curvature }\end{array}$ & $\begin{array}{c}0.862,0.484,0.896,0.886 \\
\mathbf{0 . 0 1 8} \\
0.204 \\
0.505 \\
0.089\end{array}$ & 18 & 67 \\
\hline D4 & $\begin{array}{l}\text { Diver collected } \\
\text { (full) }\end{array}$ & $\begin{array}{l}\text { Microhabitat (1, } 2 \text { or } 3 \text { types) } \\
\text { Grouper density }\end{array}$ & $\begin{array}{c}0.250,<\mathbf{0 . 0 0 0 1},<\mathbf{0 . 0 0 1} \\
0.063\end{array}$ & 47 & 49 \\
\hline D5 & $\begin{array}{l}\text { Diver collected } \\
\text { (biotic) }\end{array}$ & Grouper density & $<0.001$ & 17 & 42 \\
\hline D6 & $\begin{array}{l}\text { Diver collected } \\
\text { (habitat) }\end{array}$ & Microhabitat (1, 2 or 3 types) & $0.033,<0.0001,<0.0001$ & 44 & 44 \\
\hline
\end{tabular}


plained $47 \%$ of the deviance. Model D5, which used only the density of native grouper, accurately predicted lionfish density $42 \%$ of the time (GAM, p = 0.001 , Table 3 ) and explained $17 \%$ of the deviance. Model D6 used only the diver-collected microhabitat variables and accurately predicted lionfish density $44 \%$ of the time $(\mathrm{GAM}, \mathrm{p}=0.033,<0.0001$, and $<0.0001$ for the presence of 1,2 or 3 types of features, respectively; Table 3 ), and explained $44 \%$ of the deviance.

Lionfish density was positively correlated to prey density on reefs with multiple classes of microhabitat features (GLM, $\mathrm{p}=0.0379$ ).

\section{DISCUSSION}

This study demonstrated that lionfish presence, absence, and density can be predicted with varying accuracy using multiple types and resolutions of data. Remotely sensed data and derived bathymetry products had a fairly high predictive accuracy (67-76\%) but did not explain a high percentage of the deviance in the model (18-38\%). Adding diver-collected microhabitat observations greatly increased the deviance explained by the models for lionfish presence/absence and density by $\sim 30 \%$. Adding diver-collected data on the density of groupers, which are native predators, improved the deviance explained by the model for lionfish density by another $2 \%$ relative to the model based on physical variables only, but was not included in the final best-fit model for lionfish presence and absence.

Broad-scale remotely sensed data provide suitable information for mapping species distributions. These types of data are easily accessed by the public and do not require many skills to analyze. However, for 'resting' during daylight hours, lionfish prefer habitat features of $<2 \mathrm{~m}$ resolution. This key habitat component was missed by satellite-derived remotely sensed data, both because of the top-down nature of the images and the constraints on resolution. The best fit for presence and absence was provided by model PA1 (deviance explained: $68 \%$, predictive accuracy: $89 \%$, and used remotely sensed seafloor habitat and benthic features as well as the diver-collected microhabitat data. In this study, divers used a simple classification system based on the presence of certain features, which made collection of the microhabitat features data easy. Higher-resolution remotely sensed imagery might improve detection of microhabitat features, but the success of these techniques likely depends on the depth of the seafloor and would still not be capable of detecting features such as caves or overhanging ledges.

The techniques used in this study are similar to many previous efforts to model species distribution (Brotons et al. 2004, Rodríguez-Castañeda et al. 2012). However, few habitat modeling studies of any marine species have been conducted in the Bahamas (but see Stoner 2003 for queen conch, Machemer et al. 2012 for parrotfishes). Similar to other studies, the use of both presence and absence data creates a more accurate model of species distribution than a model using only one or the other (Brotons et al. 2004). This is especially true for species (such as lionfish) that have broad habitat ranges and can be tolerant of many environmental conditions (Barbour et al. 2010, Jud \& Layman 2012, Kulbicki et al. 2012, Cure et al. 2014, Loerch et al. 2015). The ability of divers to exhaustively search reefs at most of the sites used in this study was high, so the overall confidence in the presence and absence observations was high. The false absences (i.e. misses, predicting an absence when there was actually a presence) reported when validating the models ranged from $0 \%$ in multiple models to $23 \%$ in Model PA3. The false presences (i.e. fallout, predicting a presence when there was actually an absence) detected ranged from 8 to $20 \%$, with Model PA2 having the lowest false presence rate $(8 \%)$, and Model PA4 having the highest (20\%). This suggests a trade-off within the models in their ability to accurately predict presence versus absence. This distinction can be crucial for invasive species management, because an accurate map of potential presence points is important for removal efforts.

Although grouper density was significant in some of the models for both lionfish density and presence, the relationship did not appear to be linear. For example, one location that was predicted to have high lionfish densities had none at the time of the survey. However, that survey location had one of the highest densities of Nassau grouper and other large-bodied groupers seen in the survey area. In fact, reefs with high or low densities of groupers had low densities of lionfish, and the locations with medium grouper densities had high lionfish densities. This suggests that there may be an abiotic interaction, where reefs with both low grouper and lionfish densities are unsuitable reef-fish habitat (i.e. sand flats), as well as a biotic interaction where there is an antagonistic relationship between lionfish and groupers, and reefs can only support high densities of one or the other.

Another biotic factor that may influence lionfish distributions is the presence of large mobile invertebrates such as Caribbean spiny lobsters and long- 
spine urchins. Density data were collected on these species during the surveys, but there were not enough reefs with these species present to use them as a viable model predictor. Both lobsters and urchins occupy cracks and crevices similarly to lionfish. If the cracks and crevices are important for lionfish on the reef as the models suggest, then high densities of either species may influence lionfish densities, depending upon interspecific interactions. Anecdotally, the few reefs that had high densities of urchins supported only a few lionfish, and as the urchin density decreased throughout the summer, lionfish density increased (A. Davis unpubl. data). However, it is unknown what happened to the urchins, and since reef fish densities generally increase during the summer recruitment months, an experimental approach would be required to confirm any potential interaction.

The analysis of a subset of reefs where prey data were collected showed that lionfish density was positively correlated with reefs that had high prey density and multiple classes of microhabitat features. These results suggest that while habitat is important for lionfish distribution in their invaded range, potential for negative (via large groupers) or positive (via prey availability) biotic interactions likely influences lionfish densities and fidelity to a reef (Davis 2018). Unfortunately, collecting fish and invertebrate data will always be both labor and time intensive and may not be economical due to the effort. However, because the biotic data were more important in the density models, additional field observations of native predators and prey species may be vital to identify reefs which are vulnerable to long-term lionfish invasions. Ultimately, if managers are concerned about overall reef health and not just lionfish removal, biotic data of all species on the reef would be crucial to create a holistic reef management plan.

Additionally, managers need to think about what the goals of their management plan are and what type of system they are working in. On a series of small patch reefs $\left(1 \mathrm{~m}^{3}\right)$, Benkwitt (2015) found that the first lionfish on the reef had the largest effect on native species richness and community structure, and all subsequent lionfish had a decreasing non-linear effect. These results suggests that for this system, presence versus absence of lionfish has a greater effect on reef fish communities than lionfish density. Conversely, Green et al. (2014) found a density threshold for lionfish on larger patch reefs that represents the target number to remove in order to preserve viable biomass of native fishes. In this case, knowing the predicted density of lionfish on reefs would allow managers to target reefs that are likely to support lionfish densities over the desired threshold number for removal and conservation efforts.

This study provides novel information regarding how lionfish are distributed in the reef ecosystem of Eleuthera. The results presented here have implications for management of the lionfish invasion because they demonstrate that simple models of physical habitat based on satellite-derived bathymetry provide a good approximation of where lionfish may occur. In addition, the methods for habitat modeling described here may be used to locate lionfish in other parts of the invaded range.

Acknowledgements. I thank my major adviser M. Hixon for his guidance. I am also grateful for the constructive comments and guidance from my co-adviser J. Jones, and my statistics adviser C. Wickham. I also thank E. Anderson, C. Benkwitt, E. Dilley, K. Dzilenski, T. Kindinger, and L. Tuttle for assistance in the field, and the staff members of Cape Eleuthera Institute for logistical support, specifically R. Mackey, T. Hall, R. Knight, and J. Curtis-Quick. All fish were handled and collected with permits from the Bahamas Department of Marine Resources and were handled under the approval of Oregon State University's Institutional Animal Care and Use Committee. This study was supported by National Science Foundation (NSF) research grant to M. Hixon (OCE-1233027) and an NSF Graduate Research Fellowship to A.C.D.D.

\section{LITERATURE CITED}

Albins MA (2015) Invasive Pacific lionfish Pterois volitans reduce abundance and species richness of native Bahamian coral-reef fishes. Mar Ecol Prog Ser 522:231-243

Albins MA, Hixon MA (2008) Invasive Indo-Pacific lionfish Pterois volitans reduce recruitment of Atlantic coral-reef fishes. Mar Ecol Prog Ser 367:233-238

Araújo MB, Guisan A (2006) Five (or so) challenges for species distribution modelling. J Biogeogr 33:1677-1688

* Arredondo-Chávez AT, Sánchez-Jimenez J, Ávila-Morales O, Torres-Chávez P and others (2016) Spatio-temporal variation in the diet composition of red lionfish, Pterois volitans (Actinopterygii: Scorpaeniformes: Scorpaenidae), in the Mexican Caribbean: insights into the ecological effect of the alien invasion. Acta Ichthyol Piscat 46:185-200

Baltz DM, Moyle PB (1993) Invasion resistance to introduced species by a native assemblage of California stream fishes. Ecol Appl 3:246-255

* Barbour AB, Montgomery ML, Adamson AA, Díaz-Ferguson E, Silliman BR (2010) Mangrove use by the invasive lionfish Pterois volitans. Mar Ecol Prog Ser 401:291-294

*Benkwitt CE (2013) Density-dependent growth in invasive lionfish (Pterois volitans). PLOS ONE 8:e66995

Benkwitt CE (2015) Non-linear effects of invasive lionfish density on native coral-reef fish communities. Biol Invasions 17:1383-1395

*Benkwitt CE (2016a) Central-place foraging and ecological effects of an invasive predator across multiple habitats. Ecology 97:2729-2739 
Benkwitt CE (2016b) Invasive lionfish increase activity and foraging movements at greater local densities. Mar Ecol Prog Ser 558:255-266

Brotons L, Thuiller W, Araújo MB, Hirzel AH (2004) Presenceabsence versus presence-only modelling methods for predicting bird habitat suitability. Ecography 27:437-448

Byun C, Lee EJ (2017) Ecological application of biotic resistance to control the invasion of an invasive plant, Ageratina altissima. Ecol Evol 7:2181-2192

Catford JA, Vesk PA, White MD, Wintle BA (2011) Hotspots of plant invasion predicted by propagule pressure and ecosystem characteristics. Divers Distrib 17:1099-1110

* Colautti RI, Ricciardi A, Grigorovich IA, MacIsaac HJ (2004) Is invasion success explained by the enemy release hypothesis? Ecol Lett 7:721-733

Collinge SK, Ray C, Gerhardt F (2011) Long-term dynamics of biotic and abiotic resistance to exotic species invasion in restored vernal pool plant communities. Ecol Appl 21: 2105-2118

Côté IM, Green SJ, Morris JA, Akins JL, Steinke D (2013) Diet richness of invasive Indo-Pacific lionfish revealed by DNA barcoding. Mar Ecol Prog Ser 472:249-256

* Cure K, Mcllwain JL, Hixon MA (2014) Habitat plasticity in native Pacific red lionfish Pterois volitans facilitates successful invasion of the Atlantic. Mar Ecol Prog Ser 506: 243-253

* Dahl KA, Patterson WF (2014) Habitat-specific density and diet of rapidly expanding invasive red lionfish, Pterois volitans, populations in the Northern Gulf of Mexico. PLOS ONE 9:e105852

Davis ACD (2018) Habitat use and ecological interactions of invasive lionfish in the Bahamas. PhD dissertation, Oregon State University, Corvallis, OR

de León R, Vane K, Bertuol P, Chamberland VC, Simal F, Imms E, Vermeij MJA (2013) Effectiveness of lionfish removal efforts in the southern Caribbean. Endang Species Res 22:175-182

Ellis RD, Faletti ME (2016) Native grouper indirectly ameliorates the negative effects of invasive lionfish. Mar Ecol Prog Ser 558:267-279

Evangelista PH, Young NE, Schofield PJ, Jarnevich CS (2016) Modeling suitable habitat of invasive red lionfish Pterois volitans (Linnaeus, 1758) in North and South America's coastal waters. Aquat Invasions 11:313-326

Fishelson L (1997) Experiments and observations on food consumption, growth and starvation in Dendrochirus brachypterus and Pterois volitans (Pteroinae, Scorpaenidae). Environ Biol Fishes 50:391-403

Frazer TK, Jacoby CA, Edwards MA, Barry SC, Manfrino CM (2012) Coping with the lionfish invasion: Can targeted removals yield beneficial effects? Rev Fish Sci 20:185-191

Gallien L, Douzet R, Pratte S, Zimmermann NE, Thuiller W (2012) Invasive species distribution models — how violating the equilibrium assumption can create new insights. Glob Ecol Biogeogr 21:1126-1136

* Gratwicke B, Speight M (2005) Effects of habitat complexity on Caribbean marine fish assemblages. Mar Ecol Prog Ser 292:301-310

Green SJ, Dulvy NK, Brooks AML, Akins JL, Cooper AB, Miller S, Côté IM (2014) Linking removal targets to the ecological effects of invaders: a predictive model and field test. Ecol Appl 24:1311-1322

Guisan A, Thuiller W (2005) Predicting species distribution: offering more than simple habitat models. Ecol Lett 8: 993-1009
Hackerott S, Valdivia A, Green SJ, Côté IM and others (2013) Native predators do not influence invasion success of Pacific lionfish on Caribbean reefs. PLOS ONE 8: e68259

Ingeman KE (2016) Lionfish cause increased mortality rates and drive local extirpation of native prey. Mar Ecol Prog Ser 558:235-245

* Ingeman KE, Webster MS (2015) Native prey mortality increases but remains density-dependent following lionfish invasion. Mar Ecol Prog Ser 531:241-252

Jud ZR, Layman CA (2012) Site fidelity and movement patterns of invasive lionfish, Pterois spp., in a Florida estuary. J Exp Mar Biol Ecol 414-415:69-74

Keane RM, Crawley MJ (2002) Exotic plant invasions and the enemy release hypothesis. Trends Ecol Evol 17:164-170

Kimbro DL, Cheng BS, Grosholz ED (2013) Biotic resistance in marine environments. Ecol Lett 16:821-833

Kindinger TL, Albins MA (2017) Consumptive and non-consumptive effects of an invasive marine predator on native coral-reef herbivores. Biol Invasions 19:131-146

Kindinger TL, Anderson ER (2016) Preferences of invasive lionfish and native grouper between congeneric prey fishes. Mar Ecol Prog Ser 558:247-253

Koshkina V, Wang Y, Gordon A, Dorazio RM, White M, Stone L (2017) Integrated species distribution models: combining presence-background data and site-occupancy data with imperfect detection. Methods Ecol Evol 8:420-430

Kulbicki M, Beets J, Chabanet P, Cure K and others (2012) Distributions of Indo-Pacific lionfishes Pterois spp. in their native ranges: implications for the Atlantic invasion. Mar Ecol Prog Ser 446:189-205

Kesser MP, Slattery M (2011) Phase shift to algal dominated communities at mesophotic depths associated with lionfish (Pterois volitans) invasion on a Bahamian coral reef. Biol Invasions 13:1855-1868

Loerch SM, McCammon AM, Sikkel PC (2015) Low susceptibility of invasive Indo-Pacific lionfish Pterois volitans to ectoparasitic Neobenedenia in the eastern Caribbean. Environ Biol Fishes 98:1979-1985

* Machemer EGP, Walter JF III, Serafy JE, Kerstetter DW (2012) Importance of mangrove shorelines for rainbow parrotfish Scarus guacamaia: habitat suitability modeling in a subtropical bay. Aquat Biol 15:87-98

McComb B, Zuckerberg B, Vesely D, Jordan C (2010) Monitoring animal populations and their habitats: a practitioner's guide. CRC Press, Boca Raton, FL

* Molnar JL, Gamboa RL, Revenga C, Spalding MD (2008) Assessing the global threat of invasive species to marine biodiversity. Front Ecol Environ 6:485-492

Morris JA, Akins JL (2009) Feeding ecology of invasive lionfish (Pterois volitans) in the Bahamian archipelago. Environ Biol Fishes 86:389-398

Nuttall MF, Johnston MA, Eckert RJ, Embesi JA, Hickerson EL, Schmahl GP (2014) Lionfish (Pterois volitans [Linnaeus, 1758] and $P$. miles [Bennett, 1828]) records within mesophotic depth ranges on natural banks in the Northwestern Gulf of Mexico. BioInvasions Rec 3:111-115

Petitpierre B, Kueffer C, Broennimann O, Randin C, Daehler C, Guisan A (2012) Climactic niche shifts are rare among terrestrial plant invaders. Science 335:1344-1347

* Pimiento C, Nifong JC, Hunter ME, Monaco E, Silliman BR (2015) Habitat use patterns of the invasive red lionfish Pterois volitans: a comparison between mangrove and reef systems in San Salvador, Bahamas. Mar Ecol 36:28-37 
Pittman SJ, Olds AD (2015) Seascape ecology of fishes on coral reefs. In: Mora C (ed) Ecology of fishes on coral reefs. Cambridge University Press, Cambridge, p 274-282

Pittman SJ, Christensen JD, Caldow C, Menza C, Monaco ME (2007) Predictive mapping of fish species richness across shallow-water seascapes in the Caribbean. Ecol Model 204:9-21

Pusack TJ (2013) Coral-reef fishes: insights into larval dispersal and invasion ecology. $\mathrm{PhD}$ dissertation, Oregon State University, Corvallis, OR

Pusack TJ, Christie MR, Johnson DW, Stallings CD, Hixon MA (2014) Spatial and temporal patterns of larval dispersal in a coral-reef fish metapopulation: evidence of variable reproductive success. Mol Ecol 23:3396-3408

Pyšek P, Richardson DM (2010) Invasive species, environmental change and management, and health. Annu Rev Environ Resour 35:25-55

R Development Core Team (2008) R: a language and environment for statistical computing. R Foundation for Statistical Computing, Vienna

Raymond WW, Albins MA, Pusack TJ (2015) Competitive interactions for shelter between invasive Pacific red lionfish and native Nassau grouper. Environ Biol Fishes 98: $57-65$

Rilov G, Figueira WF, Lyman SJ, Crowder LB (2007) Complex habitats may not always benefit prey: linking visual field with reef fish behavior and distribution. Mar Ecol Prog Ser 329:225-238

Roberts JJ, Best BD, Dunn DC, Treml EA, Halpin PN (2010) Marine Geospatial Ecology Tools: an integrated framework for ecological geoprocessing with ArcGIS, Python, R, MATLAB, and C++. Environ Model Softw 25:11971207

Robinson LM, Elith J, Hobday AJ, Pearson RG, Kendall BE, Possingham HP, Richardson AJ (2011) Pushing the limits in marine species distribution modelling: lessons from the land present challenges and opportunities. Glob Ecol Biogeogr 20:789-802

Rodríguez-Castañeda G, Hof AR, Jansson R, Harding LE (2012) Predicting the fate of biodiversity using species' distribution models: enhancing model comparability and repeatability. PLOS ONE 7:e44402

Roelfsema C, Kovacs E, Ortiz JC, Wolff NH and others (2018) Coral reef habitat mapping: a combination of object-based image analysis and ecological modelling. Remote Sens Environ 208:27-41

Editorial responsibility: Janet Ley, St. Petersburg, Florida, USA
Schofield PJ (2009) Geographic extent and chronology of the invasion of non-native lionfish (Pterois volitans [Linnaeus 1758] and $P$. miles [Bennett 1828]) in the Western North Atlantic and Caribbean Sea. Aquat Invasions 4: 473-479

Schofield PJ (2010) Update on geographic spread of invasive lionfishes (Pterois volitans [Linnaeus, 1758] and P. miles [Bennett, 1828]) in the Western North Atlantic Ocean, Caribbean Sea and Gulf of Mexico. Aquat Invasions 5(Suppl 1):S117-S122

Stoner AW (2003) What constitutes essential nursery habitat for a marine species? A case study of habitat form and function for queen conch. Mar Ecol Prog Ser 257:275-289

* Tuttle LJ (2017) Direct and indirect effects of invasive lionfish on coral-reef cleaning mutualists. Mar Ecol Prog Ser 569:163-172

* Usseglio P, Selwyn JD, Downey-Wall AM, Hogan JD (2017) Effectiveness of removals of the invasive lionfish: How many dives are needed to deplete a reef? PeerJ 5:e3043

*Václavík T, Meentemeyer RK (2009) Invasive species distribution modeling (iSDM): Are absence data and dispersal constraints needed to predict actual distributions? Ecol Model 220:3248-3258

Valdez-Moreno M, Quintal-Lizama C, Gómez-Lozano R, Carmen García-Rivas M (2012) Monitoring an alien invasion: DNA barcoding and the identification of lionfish and their prey on coral reefs of the Mexican Caribbean. PLOS ONE 7:e36636

Walbridge S, Slocum N, Pobuda M, Wright DJ (2018) Unified geomorphological analysis workflows with Benthic Terrain Modeler. Geosciences 8:94

*Whitfield PE, Hare JA, David AW, Harter SL, Muñoz RC, Addison CM (2007) Abundance estimates of the IndoPacific lionfish Pterois volitans/miles complex in the Western North Atlantic. Biol Invasions 9:53-64

W Wright DJ, Pendleton M, Boulware J, Walbridge S and others (2012) ArcGIS Benthic Terrain Modeler (BTM), v. 3.0, Environmental Systems Research Institute, NOAA Coastal Services Center, Massachusetts Office of Coastal Zone Management. http://esriurl.com/5754

* Young M, Iampietro P, Kvitek R, Garza C (2010) Multivariate bathymetry-derived generalized linear model accurately predicts rockfish distribution on Cordell Bank, California, USA. Mar Ecol Prog Ser 415:247-261

Zuur AF, Ieno EN, Meesters E (2009) A beginner's guide to R. Springer, New York, NY

Submitted: October 11, 2018; Accepted: July 9, 2019

Proofs received from author(s): July 26, 2019 